\title{
Manly Minds in Female Bodies: Three Women and their Power through Coins and Seals*
}

\author{
Mentes masculinas en cuerpos femeninos.
}

Tres mujeres y su poder a través de monedas y sellos

Humboldt-Universität zu Berlin

Jitske Jasperse

jitske.jasperse@hu-berlin.de

Recibido el 9 de julio de 2018

Aceptado el 15 de octubre de 2018

[1134-6396(2018)25:2; 295-321]

http://dx.doi.org/10.30827/arenal.v25i2.7640

\section{RESUMEN}

En este artículo las monedas y los sellos se analizan como herramientas que reflejan el deseo de las mujeres gobernantes de autorepresentarse y de ser así recordadas. Un recorrido por estos objetos pequeños pero muy relevantes conectados con la reina Urraca de León-Castilla (r. 1109-1126), la emperatriz Matilde de Inglaterra (r. 1135-1154) y la duquesa Berta de Lorena (r. 1176-1194/95) mostrará que cada una construyó una imagen visual de su reinado, empleando una iconografía masculina para crear sus identidades. Procedentes directamente del poder de estas mujeres señoriales, su moneda y los sellos expresan cómo ellas se representaban y, en consecuencia, cómo deseaban ser reconocidos y recordados. Por definición, estos objetos formaban parte de una cultura medieval de memoria para la cual era crucial la creación de artefactos y arquitectura.

Palabras clave: Género. Monedas. Sellos. Arte. Reina Urraca de León-Castilla. Emperatriz Matilde de Inglaterra. Duquesa Berta de Lorena. Siglo XII.

\section{ABSTRACT}

This article investigates coins and seals as instruments that reflect the desire for self-representation and remembrance of ruling women. An analysis of these small but important objects connected to Queen Urraca of León-Castilla (r. 1109-1126), Empress Matilda of England (r. 1135-1154), and

* I would like to thank Therese Martin, Marije Osnabrugge, Joana Ramôa Melo and Ana Rodríguez for their insightful comments. This article was written during my postdoctoral fellowship at the Instituto de Historia, Consejo Superior de Investigaciones Científicas, Madrid (Juan de la Cierva-Formación, FJCI-2014-22406) within the framework of a National Excellence in Research Grant, "The Medieval Treasury across Frontiers and Generations: The Kingdom of León-Castilla in the Context of Muslim-Christian Interchange, c. 1050-1200" (PI, Therese Martin, Spanish Ministry of Economy and Competitivity, HAR2015-68614-P). 
Duchess Bertha of Lorraine (r. 1176-1194/95), will show that they each constructed the visual image of their rule by employing a masculine iconography to craft their identities. Originating directly from the power these lordly women, their coins and seals convey how they represented themselves and consequently how they wished to be recognized and recollected. As such, these objects were part of a wider medieval memorial culture to which the creation of artefacts and architecture was crucial.

Key words: Gender. Coins. Seals. Art. Queen Urraca of León-Castilla. Empress Matilda of England. Duchess Bertha of Lorraine. Twelfth century.

\section{SUMMARY}

1.- Introduction. 2.- Queen Urraca: Creating the Image of a King. 3.-Empress Matilda: A Manly Mind in a Female Body. 4.-Duchess Bertha of Lorraine: Riding Astride Like a Man. 5.-Conclusion. 6.-Bibliography.

\section{1.--Introduction}

In the Middle Ages seals and coins counted among the "miniature yet mighty expressions of medieval art," holding an importance to secular and ecclesiastical rulers which has not gone unnoticed by medievalists ${ }^{1}$. By impressing a clever combination of text and image into wax and metal, elite men and women promoted their status and with it their identity. Over the past decades, women as owners of seals and as issuers of coinage has been studied in some depth ${ }^{2}$. The relationship between the visual elements of the seal and the communication of the status of elite women has interested art historians in particular ${ }^{3}$. The fact that many seals are

1. Coins and seals are studied together in SOLWAY, Susan: "Introduction". In SOLWAY, Susan (ed.): Medieval coins and seals: constructing identity, signifying power. Turnhout, Brepols, 2015, p. 20.

2. For coins, see STAHL, Alan M.: "Coinage in the name of medieval women". In ROSENTHAL, Joel T. (ed.): Medieval women and the sources of medieval history. Athens, Ga., The University of Georgia Press, 1990, pp. 321-341; MONTER, William: "Gendered sovereignty: Numismatics and female monarchs in Europe, 1300-1800". Journal of Interdisciplinary History 41-4 (2011) 533-564. For seals, see STIELDORF, Andrea: "Die Siegel der Herrscherinnen. Siegelführung und Siegelbilder der deutschen Kaiserinnen und Königinnen”. Rheinische Vierteljahrsblätter 64 (2000) 1-44; JOHNS, Susan M.: Noblewomen, aristocracy and power in the twelfth-century Anglo-Norman realm. Manchester: Manchester University Press, 2003; NIELEN, Marie-Adélaïde: Corpus des sceaux français du Moyen âge 3. Tome III, Les sceaux des reines et des enfants de France. Paris, Service interministériel des Archives de France, 2011; and Part III "Medieval women: coining identity, sealing power". In SOLWAY, 2015, op cit.

3. BEDOS-REZAK, Brigitte: "Women, seals and power in medieval France, 1150-1350". In ERLER, M. and KOWALESKI, M. (eds.): Women and power in the Middle Ages. Athens, Ga., and London, The University of Georgia Press, 1988, pp. 61-82; SERRANO COLL, Marta: "Iconografía de género. Los sellos de las reinas de Aragón en la Edad Media (siglos XII-XVI)". Emblemata 12 
no longer appended to the original charters does however hamper a more nuanced appreciation of seals, as it obscures the context in which the seals were used, as well as its possible audiences. In addition, our understanding of coinage issued by women (and men) is hindered by the fact that many coins were melted down in order to reuse the silver for new coins. Moreover, when specimens are known through a single find (often indicating that the owner randomly lost a coin) rather than in a hoard (a collection of coins buried at a certain moment for a specific reason) it is much more difficult to establish the time of their issue and how widely they were used.

Notwithstanding these obstacles, this article will demonstrate that case studies rather than a longue durée analysis can be fruitful in assessing the extent to which coins and seals can be interpreted as instruments that reflect the desire for self-representation and remembrance of elite women ${ }^{4}$. We will work from the premise that coins and seals were the direct and explicit result of women's power, instead of merely passive display of their status. It was women's involvement in the conception and production that made these artefacts the embodiment of their rule. An analysis of the coins and seals connected to Queen Urraca of León-Castilla (r. 1109-1126), Empress Matilda of England (r. 1135-1154), and Duchess Bertha of Lorraine (r. 1176-1194/95) respectively, will show that they each constructed the visual image of their rule by incorporating attributes that medieval society considered to be masculine and feminine. Their coins and seals are expressions and reminders of women's lordly powers, affirming that "manly minds in female bodies" were certainly not an anomaly in the central Middle Ages ${ }^{5}$. Whereas the selection of these three women is largely constricted by the availability of visual and documentary evidence, Urraca and Matilda merit further investigation because they were both proclaimed rightful successors by their fathers and consequently lived as kings rather than queens ${ }^{6}$. The case of Duchess Bertha serves to underscore that some high-ranking noblewomen were similarly aware that they could make

(2006) 15-52; and NOLAN, Kathleen: Queens in stone and silver: The creation of a visual imagery of queenship in Capetian France. New York, Palgrave Macmillan, 2009.

4. For example JASPERSE, Jitske: "A coin bearing testimony to Duchess Matilda as consors regni". Haskins Society Journal 26 (2014) 169-190; and KLÖSSEL-LUCKHARDT, Barbara: "Et sigillo illustris uxoris nostre - Weibliche Repräsentation in frühen Frauensiegeln des Welfenhauses". In LEMBKE, Katja, LUCKHARDT, Jochen and STAMM, Rainer (eds.): Niederdeutsche Beiträge zur Kunstgeschichte, Neue Folge, Band 2. Petersberg, Michael Imhof Verlag, 2017, pp. 27-52.

5. On this topic, see LOPRETE, Kimberly A.: "Gendering viragos. Medieval perceptions of powerful women". In MEEK, Catherine and LAWLESS, Catherine (eds.): Studies on medieval and early modern women 4: Victims or viragos? Dublin, Four Courts Press, 2005, pp. 17-38.

6. A comparative study was made by Therese Martin, but coins and seals were not extensively analyzed. See MARTIN, Therese: "The art of a reigning queen as dynastic propaganda in twelfthcentury Spain”. Speculum 80-4 (Oct., 2005) 1134-1171. 
use of seals to craft their image and preserve their memory, despite the fact that they were not rulers in their own right.

\section{2.-Queen Urraca: Creating the Image of a King}

When King Alfonso VI of León-Castilla died in July 1109, his daughter Urraca (r. 1109-1126) — born from his second marriage to Constance of Burgundyinherited the throne and with it the minting rights that enabled her to issue her own coinage in the same way as her father had done ${ }^{7}$. In the course of her reign, Urraca had mints in León and Toledo, her most important holdings, and added several others, such as the one in Sahagún ${ }^{8}$. The town of Sahagún was located halfway between León and Palencia and as such in the center of her power base, while also conveniently situated along the pilgrim route to Santiago de Compostela where pilgrims would spend their silver that Urraca could then reuse to mint her coins ${ }^{9}$. Minting places were consciously created in order to emphasize power bases, to generate income, to foster alliances, and to support warfare. In this respect Urraca operated no different from her father, although she was the first Iberian queen to issue coinage ${ }^{10}$.

7. Urraca was not the only one to mint coinage during her reign, as her son Alfonso Raimundo, the abbot of Sahagún, the bishop of Palencia, her (former) husband Alfonso the Battler of Aragon, and the bishop of Santiago de Compostela also issued coinage, although the first three did so with the permission of Urraca. See ROMA VALDÉS, Antonio: "Notas sobre las acuñaciones medievales leonesas: primeros escritos conocidos y las emisiones de Doña Urraca". OMNI 10-7 (2016) 64. For Urraca, see MARTIN, Therese: Queen as king. Politics and architectural propaganda in twelfth-century Spain. Leiden, Brill, 2006; and PALLARÉS MÉNDEZ, María del Carmen and PORTELA SILVA, Ermelindo: La reina Urraca. Donostia, Nerea, 2006. Coinage is not discussed in these studies.

8. For Sahagún, see CRUSAFONT, Miguel, BALAGUER, Anna M. and GRIERSON, Philip (eds.): Medieval European coinage: With a catalogue of the coins in the Fitzwilliam Museum, Cambridge. 6: The Iberian Peninsula. Cambridge, Cambridge University Press, 2013, pp. 232-233; TODESCA, James J.: What touches all: Coinage and monetary policy in Leon-Castile to 1230 (PhDdiss.). Fordham University, New York, 1996, pp. 219-226.

9. TODESCA, 1996, op. cit., p. 225.

10. For the larger tradition of Leonese royal daughters, see CAVERO, Gregoria: "Sancha Raimúndez: An infanta in the exercise of her power". Imago Temporis. Medium Aevum 7 (2013) 271-297; HENRIET, Patrick: "Infantes, Infantaticum. Remarques introductives". e-Spania[En ligne], 5 | juin 2008, mis en ligne le 29 janvier 2014. URL: http://e-spania.revues.org/12593; and CAYROL BERNARDO, Laura: "De infantas, domnae y Deo votae. Algunas reflexiones en torno al infantado y sus senoras". SVMMA 3 (2014) 5-23. 
Several coin types minted by Urraca are known but it is extremely difficult to establish their chronology, which complicates the effort to place them in a specific historical context ${ }^{11}$.

The first coin type that is of interest for our current research was discussed by Therese Martin within the context of the subsidizing of Urraca's military enterprises $^{12}$. On the reverse the inscription TOLETVO can be read, while on the obverse the queen's face is depicted frontally, her head adorned with a delicate diadem [fig. 1]. The bust is bordered by an inscription that reads +VRRACA RE. As Martin has argued, this is neither REGINA nor REX, but an ambiguous RE, which should give us food for thought ${ }^{13}$. In fact, we are quick to interpret the inscription as regina ("queen") since Urraca was a woman, but it would not be unthinkable to interpret it as rex ("king"), considering that she did not only act as one, but even referred to herself as king in a document of 1121. In this charter she promised Archbishop Gelmírez of Santiago to be "a faithful lady and friend, as a good king (bonus rex) to his good archbishop, for my whole life" 14 . This coin type is usually placed in the first part of her reign, between July 1109 (when she ascended the

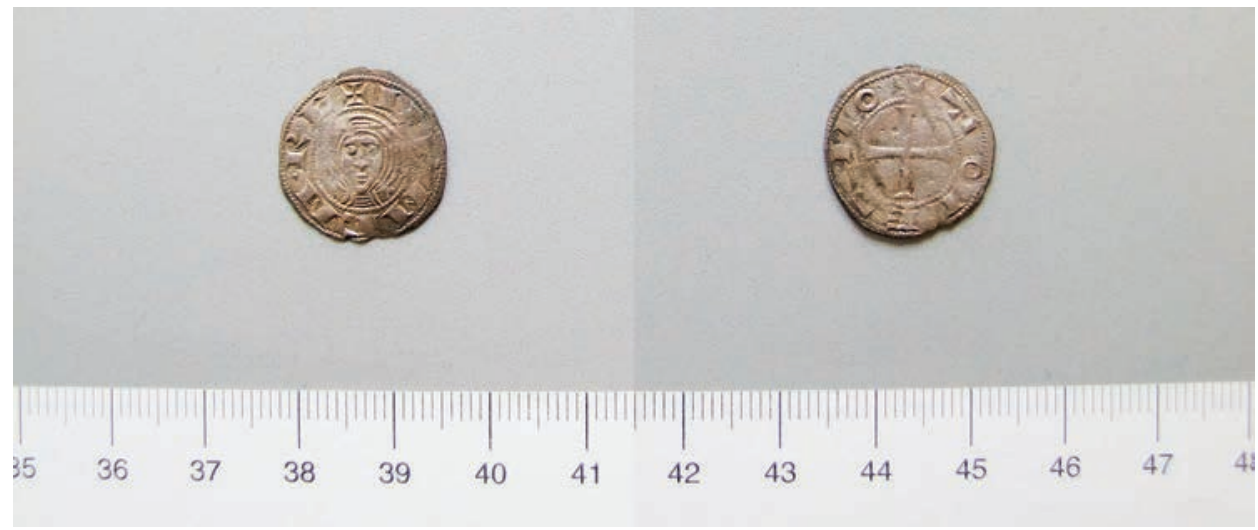

Fig. 1. Coin Urraca, Toledo, 1109-1126. Silver, 0.81 g, Ø $17.7 \mathrm{~mm}$. Photo: Yale University Art Gallery, https://artgallery.yale.edu/collections/objects/162281.

11. In 1996 James Todesca distinguished five coin types, which naturally did not include the ones discovered in 2014 and 2016, see TODESCA, 1996, op. cit., pp. 197-200. For a recent analysis of Urraca's coin types, see ROMA VALDÉS, 2016, op. cit., 68.

12. MARTIN, 2005, op. cit., 1160-1161.

13. MARTIN, 2005, op. cit., 1161.

14. Ibid. with reference to RUIZ ALBI, Irene: La Reina doña Urraca (1109-1126). Cancillería y colección diplomática. León, Centro de estudios e investigación "San Isidoro". Caja España de Inversiones y Archivo Histórico Diocesano, 2003, pp. 552-553: ... sim vobis fidelis domina et amica, sicut bonus rex suo bono archiepiscopo in tota vita mea. 
throne) and November 1116 (when her son Alfonso was granted control over the territories of Toledo $)^{15}$. Given Urraca's initiatives to connect herself to her father in order to underscore her rightful claim to the throne, the coin design seems to have imitated that of her father King Alfonso VI [fig. 2]. Very early in her reign, Urraca constructed her identity through the appropriation of her father's frontal crowned bust, thereby signaling that she did not merely think of herself as a queen, but as a king.
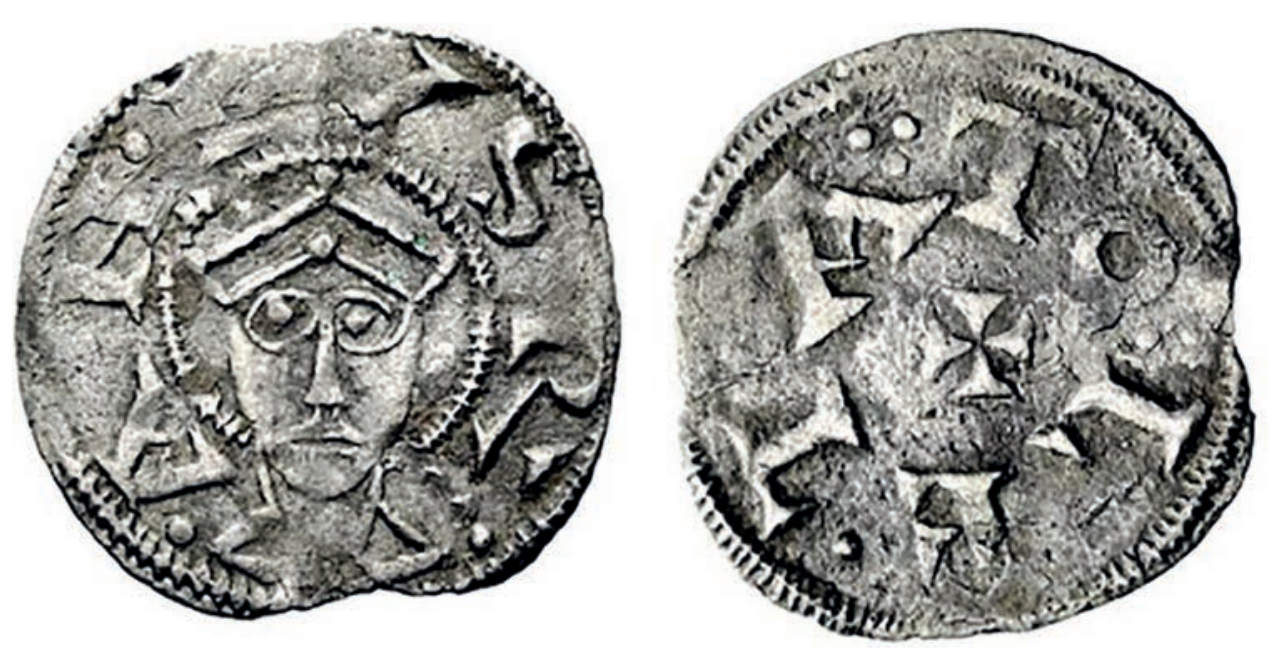

Fig. 2. Coin Alfonso VI, Toledo (shortly after conquest 25 May 1085). Silver, 0.986 g, Ø $18 \mathrm{~mm}$. American Numismatic Society - Hispanic Society, n. ${ }^{\circ}$ 1001.1.28306. https://numismaticamedieval.wordpress.com/category/alfonso-vi/

The validity of this interpretation is confirmed by another coin type issued by Urraca, which was auctioned in 2004 and only this specimen is known ${ }^{16}$. On its obverse, Urraca wears a crown and appears to hold a scepter, while the legend reads REGINA. The reverse is decorated with a cross and the inscription VRACAISPAREX. When both sides are read together the legend states "Queen / Urraca King of Ispania." It is the first time that Ispania appears on Iberian coinage, whereas the combination of Ispania and Queen (as in "Queen of Hispanie")

15. TODESCA, 1996, op. cit., 203; and ROMA VALDÉS, 2016, op. cit., 66. Crusafont et $a l$. are a bit more hesitant because rather than seeing Urraca as the originator, he suggests that this type could have been modelled after that of her son Alfonso. See: CRUSAFONT, 2013, op. cit., 229.

16. CRUSAFONT, 2013, op. cit., p. 229; ROMA VALDÉS, 2016, op. cit., 68, who does not analyze the inscription. 
frequently occurs in Urraca's charters ${ }^{17}$. The explicit use of rex is however unique, and since coins - like seals - were carefully designed it can hardly be a coincidence that Urraca chose to have her name connected to the ISPAREX and not to the REGINA, as can be found on other coin types she had minted. It is conceivable that Urraca is represented here both as queen and as the king of Hispania, a title that her father also employed in his charters - but not on his coins. In Medieval European Coinage preference is given to a different interpretation of the legend, by reading ISP A REX as alluding to A[LFONSUS]REX $^{18}$. This would either be Urraca's husband Alfonso I of Aragon (also known as the Battler), whom she married in 1109 and separated from in 1113, or her son Alfonso, who became king of Toledo in 1116 and king of Hispania in 1126. Although Miguel Crusafont and his colleagues admit that the legend could also be read as ISPAnia, they fail to consider the fact that, even though Urraca shared her reign at times, she was always the queen regnant.

Another coin type portrays Urraca's bust in profile (facing to the left) with flowing hair and a crown ${ }^{19}$. The legend encircling her bust reads VRRACA REXA. On the reverse, LEGIONENSIS, referring not to the town of León but to the kingdom, is inscribed [fig. 3]. This time Urraca visually distinguished herself from her father, although she

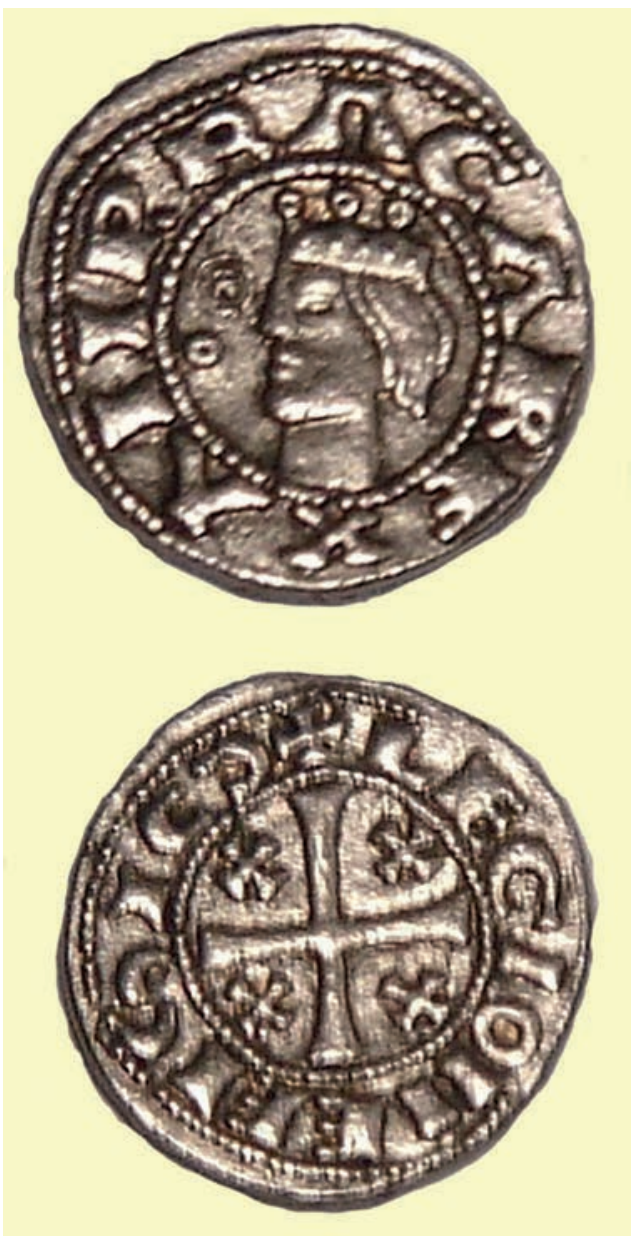

Fig. 3. Coin Urraca. Obv. VRRACA REXA, rev. +LEGIONENSIS. Photo: http://www.fonsado. com/2010/03/monedas-con-ceca-en-leon.html

17. In 81 of the 149 documents connected to Queen Urraca variations of the phrase "Hispanie" appear. RUIZ ALBI, 2003, op. cit., p. 303.

18. CRUSAFONT, 2013, op. cit., p. 229.

19. CRUSAFONT, 2013, op. cit., p. 229; and ROMA VALDÉS, 2016, op. cit., 67. 
is undisputedly depicted as a ruler. Again, the inscription is ambiguous. REXA could refer to Urraca as king, but then the A remains unexplained. In this case, it is more likely that the A is indeed a reference to her husband King Alfonso I of Aragon, who issued coins of similar design issued in Toledo [fig. 4]. Interestingly Alfonso does not wear a crown, perhaps an indication that he -as Urraca's husband - held a different authority in Toledo than Queen Urraca did.

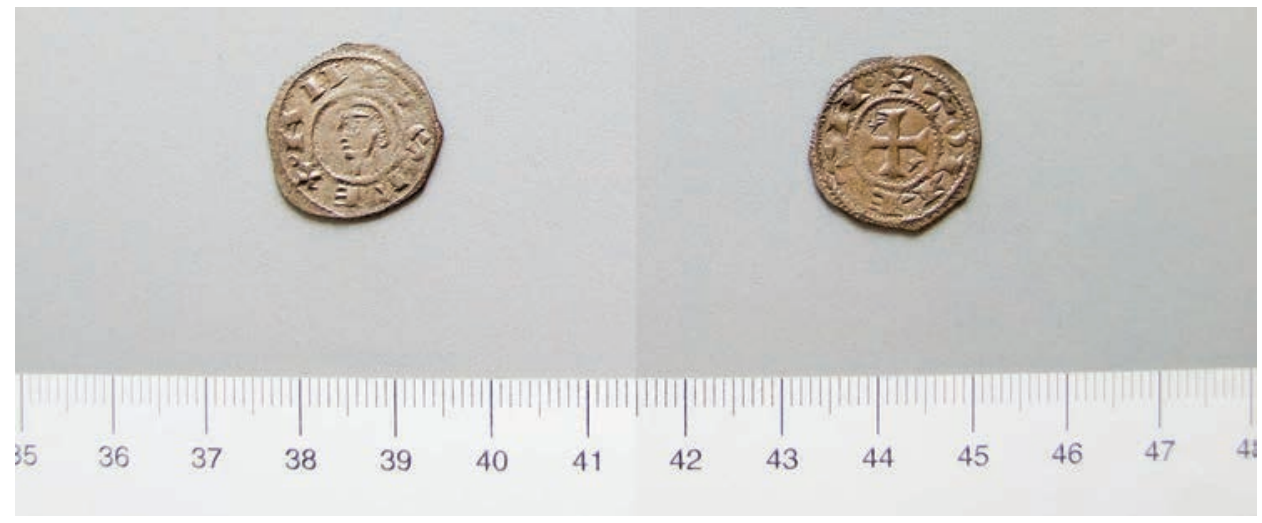

Fig. 4. Coin Alfonso I of Aragon, 1104-1134. Silver, 1.09 g, Ø 19.0 mm. Obv. ANFUS REX, rev. TOLLETA, 1109-1114. Photo: Yale University Art Gallery, https://artgallery.yale.edu/collections/ objects/162279

However, not all the inscriptions on Urraca's coins are open to interpretation. A coin type that was discovered very recently, in 2016, has an obverse with [VR] RAC REGIN and a depiction of an enthroned and crowned Urraca, holding a scepter in her left hand while raising her right hand in a gesture of authority [fig. 5]. Her dress falls in thick drapes over her body and the round clasps on her shoulders suggest that she is also wearing a mantle. On the other side, a cross and the inscription + LEGIONENSI can be discerned. This time the innovative aspect is not the legend, but, as Antonio Roma Valdés has argued, the iconography of an enthroned ruler ${ }^{20}$. Based on style, Roma Valdés suggests that Urraca issued this type of coin later in her reign. The image of the enthroned ruler was subsequently appropriated by the kings Alfonso VII and Alfonso VIII.

The variety and originality in Urraca's coinage demonstrate that through a clever combination of text and image Urraca promoted that she was a king (a social and political body) as well as a queen (a biological body). The queen's coins, like

20. ROMA VALDÉS, 2016, op. cit., 68. The image and legend can also be found on http:// www.numismaticodigital.com/noticia/9243/subastas-nacionales/piezas-muy-interesantes-en-lasubasta-144-de-jesus-vico.html. Accessed 19 December 2017. 

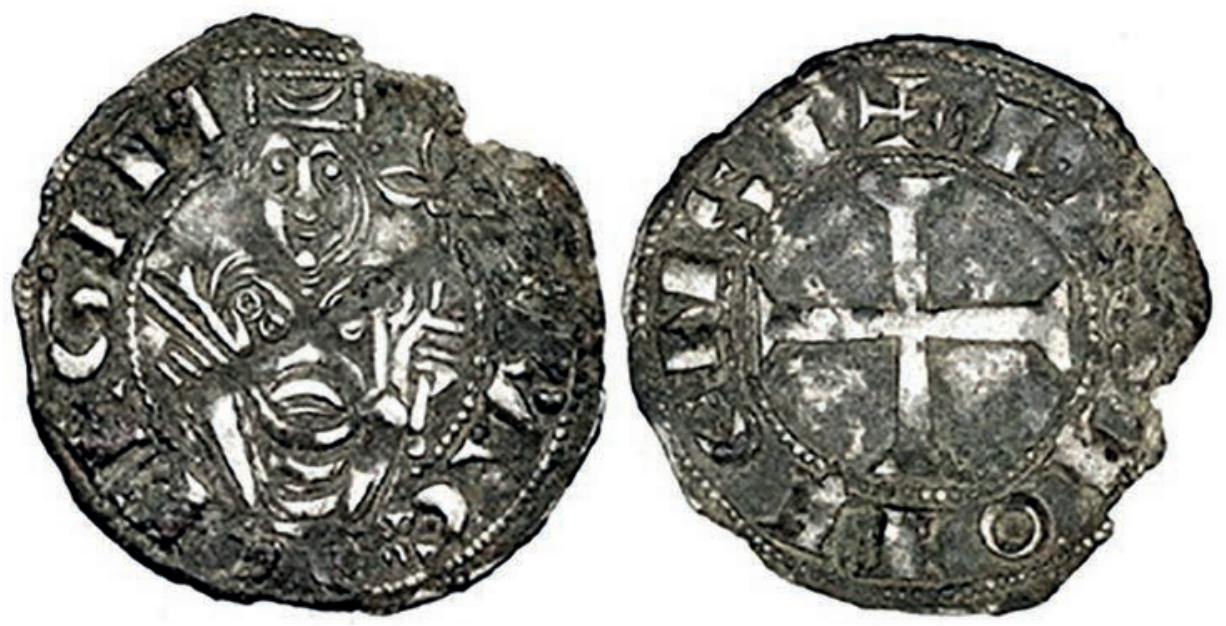

Fig. 5. Coin Urraca. Obv. --RAC REGIN., rev. +LEGIONENSI. https://www.numisbids.com/n. $\mathrm{php} ? \mathrm{p}=1 \mathrm{ot} \& \mathrm{sid}=1419 \&$ lot $=354$

her building activities in San Isidoro de León, were part of "a series of strategies that secured her place on the throne and solidified her unique position as queen regnant" $"$.

\section{3.-Empress Matilda: A Manly Mind in a Female Body}

It seems to be appropriate to approach Empress Matilda's coinage with a similar caution. Matilda, a near contemporary of Urraca, was the daughter of King Henry I of England (r. 1100-1135) and his wife Matilda of Scotland (r. 1100-1118). In 1110 she was betrothed to the German Emperor Henry V (r. 1106-1125) and four years later, in January 1114 , the couple was formally married ${ }^{22}$. After the emperor's death Matilda, now a widow, returned to her native Anglo-Norman realm. In 1127 her brother passed away, resulting in King Henry's proclamation that Matilda was his rightful heir to whom his barons were to swear fealty. ${ }^{23} \mathrm{~A}$ year later she married Count Geoffrey of Anjou. Despite the oaths taken and notwithstanding a crown-wearing ceremony, Matilda's claim to the throne was contested by her cousin Stephen of Blois, who seized the throne after King Henry's death in 1135,

21. MARTIN, 2005, op. cit., 1135.

22. CHIBNALL, Marjorie: The Empress Matilda: Queen Consort, Queen Mother and Lady of the English. Oxford, Blackwell Publishers, 1999, pp. 24-26.

23. CHIBNALL, 1999, op. cit., pp. 51-52. 
which resulted in a long war between the two parties. Without the official position of queen, Matilda chose to use the titles "empress" and "daughter of King Henry" in her charters. These designations indicate her high status as well as her rightful claim to the throne. On 2 February 1141, Matilda captured Stephen at Lincoln and a month later she was proclaimed "female lord of the English" (domina anglorum), probably considering this as a temporary title, a prelude to being crowned ${ }^{24}$. From April 1141 onwards, Matilda added the title Anglorum domina to her charters and kept doing so until 1148, when she returned to Normandy and left affairs concerning England in the hand of her son, the future King Henry $\mathrm{II}^{25}$.

From the moment Matilda set foot in England in September 1139, she had coins struck in her name at Bristol and Cardiff, where a new mint was created. On the obverse of these coins, the portrait of a crowned bust facing right and holding a sceptre was depicted, thereby closely following the design of Stephen's first coin type [figs. 6 and 7]. Around the portrait, an inscription with Matilda's name and title are legible, written as IMPERATR, IMPERA, IMPER or IMP ${ }^{26}$. The legend on the reverse, decorated with a cross, usually provides the moneyer's name and place of issue.

The different abbreviations on Matilda's coins are nothing unusual, since Stephen's title was inscribed in full as REX but also as R[EX] and RE[X]. Given Matilda's use of the title imperatrix, it is not surprising that historians have interpreted the different abbreviations on her coins in a similar vein, despite the fact that an exact reading is complicated by the poor quality of the coins' inscriptions. Perhaps the ambiguity of the legend was used to Matilda's advantage, leaving the sex of the title undecided. As such, it would allow for an interpretation that underscored her claim to the throne as a female king. This masculine reading based on the coin's inscription is nonetheless complicated by the fact that nothing in the charters or chronicles suggests that Matilda ever explicitly styled herself as male ruler, be it an emperor or future king. However, this is not to say that she did not act as a lord, or even a female king. In fact, the act of issuing coinage itself was a demonstration of lordship. The communication of Matilda's image

24. CHIBNALL, 1999: op. cit., p. 98 and p. 102. Chibnall translates domina anglorum with Lady of the English and while this is correct I prefer the translation 'female lord' as it signals that she acted in her own right and not as the wife of a lord as the term 'lady' suggests. See also LOPRETE, Kimberly A.: "The gender of lordly women: The case of Adela of Blois". In MEEK, Christine and LAWLESS, Catherine (eds.): Pawns or players? Studies on medieval and early modern women. Dublin, Four Courts Press, 2003, pp. 90-110.

25. The title empress was used after Matilda returned from Germany where she had used regina, see CHIBNALL, Marjorie: "The Charters of the Empress Matilda". In GARNET, George and HUDSON, John (eds.): Law and government in medieval England and Normandy: Essays in honor of Sir James Holt. Cambridge, Cambridge University Press, 1994, p. 277.

26. MACK, R.P.: "Stephen and the Anarchy 1135-1154". British Numismatic Journal 35 (1966) 86-88. 


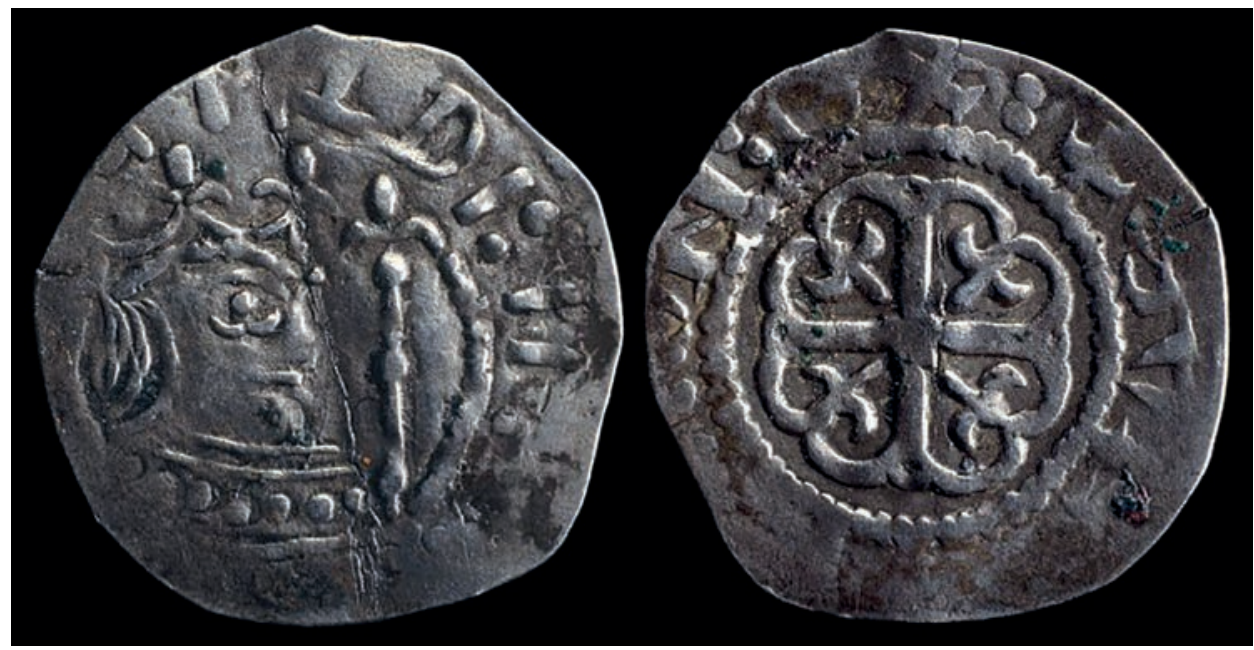

Fig. 6. Penny, Empress Matilda, 1.114g. Obv. - - - HILDI: IM - - -, rev. N:-+:+. British Museum, 1896,0609.126. CC BY-NC-SA 4.0. (C) Trustees of the British Museum.

http://www.britishmuseum.org/research/collection_online/collection_object_details/collection_ image_gallery.aspx?partid $=1 \&$ assetid $=798518001$ \&objectid $=1084846$

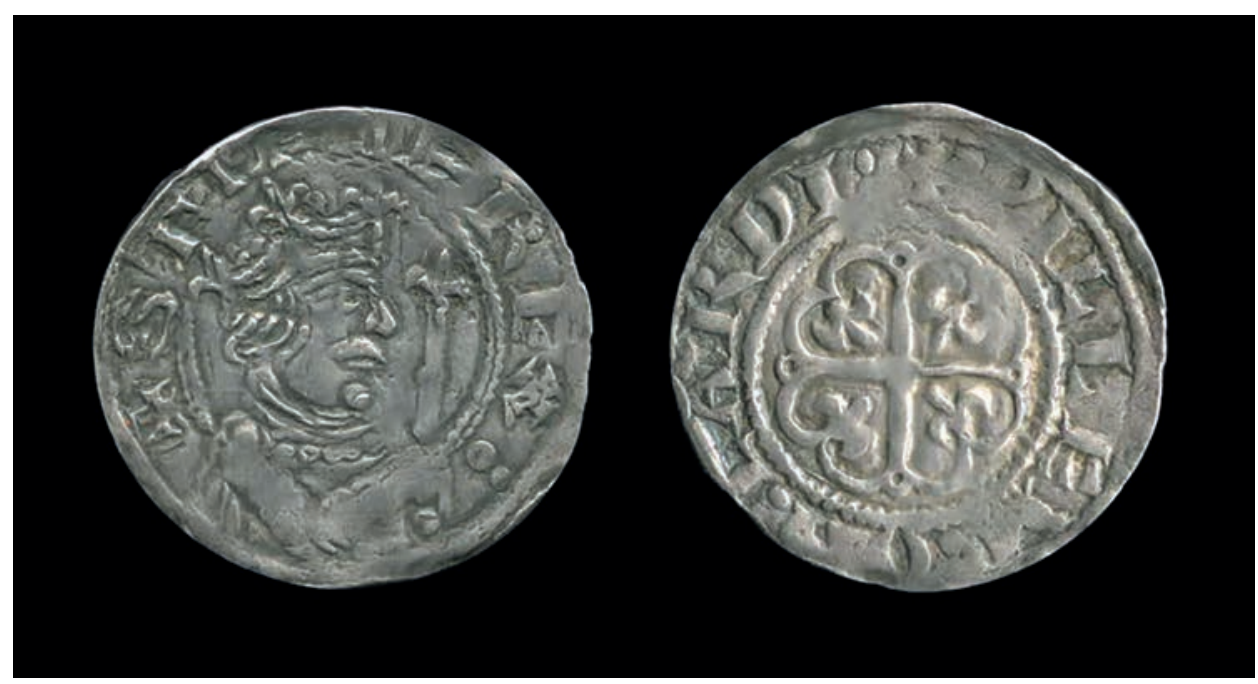

Fig. 7. Penny, King Stephen, 1.412g. Obv. + STIFNE REX :, rev. +FILLEM : ON: CARDI :. British Museum, E.5163. CC BY-NC-SA 4.0. (C) Trustees of the British Museum.

http://www.britishmuseum.org/research/collection_online/collection_object_details/collection_ image_gallery.aspx?assetId=1612916849\&objectId=1085351\&partId $=1$ 
was further strengthened by the appropriation of the traditional iconography of the male ruler on her coins, instead of inventing a new image ${ }^{27}$. Given the constant conflict with Stephen and his supporters, Matilda needed to position herself firmly and this she seems to have done by means of coinage that mirrored her opponent's image and as such competed with it. This message was unlikely to fall on deaf ears, since most of the coins circulated in the south-west of England where Matilda's supporters were found.

Matilda also visually conveyed her authority through the single-faced seal impressions that she attached to her earliest English charters and which she used throughout her life $[\text { fig. } 8]^{28}$. Since many charters are only known through later copies, and surviving originals frequently no longer have the seals attached, it is difficult to establish how often seals were appended, and how many different seals a person might have held over the course of his or her life. It is, however, undisputable that seals were very personal items because they embodied its user, sometimes even literally by leaving their fingerprints or piece of hair behind in the $\operatorname{wax}^{29}$. The person and his or her personal participation in the impression of the seal signaled both authorship (of seal and charter) and authority (of the person and

27. Matilda could also have chosen to follow the design on her father's coins, who was depicted either frontally or facing to the left. That she did not do so is perhaps another indication that she targeted Stephen specifically. For descriptions of Henry's coinage, see BROOKE, George Cyril: A catalogue of English coins in the British Museum: The Norman Kings. London, British Museum, 1916. Some of the specimens are depicted in The British Museum Collection Online, see http://www. britishmuseum.org/research/collection_online/search.aspx.

28. For Matilda's seal, see CARLESS DAVID, Henry William, WHITWELL, Robert Jowitt, and JOHNSON, Charles (eds.): Regesta regum anglo-normannorum, 1066-1154, 3 vols. Oxford, Clarendon Press, 1913, vol. 3, no. 112 (mentioning the seal in the charter, Quod ut ratum et inconcussum teneatur imperpetuum, carta me et sigilli mei privilegio sanctitum esse volui et volo.); no. 115 (fragment of a seal on tag showing the inscription ROMANO[RUM]); no. 116 ([ ...] et sigilli mei impressione confirmo [...], with a perfect seal of the empress (in bag of blue and gold damask) on a leather thong, which has been passed through a slit in the fold and noosed, one end of the thong having been passed through a triangular aperture in the centre of the thong); nos. 368 and 370 (both mentioning the seal in the charter, Quod ut ratum et inconcussum teneatur imperpetuum, carta me et sigilli mei privilegio sanctitum esse volui et volo.); no. 392 (seal in white wax on a tongue); no. 394 (seal in white wax on a tongue); no. 409 (fragment of white wax on a white silk cord); no. 607 ([...] sigilli mei munimine confirmo et coroboro.); no. 628 (seal in grey wax on tongue MATHILDIS DEI GRAT[--] [--]EGINA), no. 651 (with a fine impression of Matilda's seal in white wax on a tongue); no. 697 (with fold and white leather tag, now broken, but no seal); no. 748 (with a fold and portion of the seal in red wax on green silk cords), no. 826 ([...] sigilli mei privilegio corrobor.); no. 843 ([...] et sigilli mei impression [...]); and no. 910 ([...] sigilli mei impression signavi [...]).

29. The personal nature of seals is also evident from the fact that they sometimes were buried with their owners. This was done to avoid fraudulent use, but could also have symbolic and theological reasons. See: NEW, Elizabeth E.: "Episcopal Embodiment: The Tombs and Seals of Bishops". In HEALE, Martin (ed.): The Prelate in England and Europe, 1300-1500. Woodbridge, Boydell \& Brewer, 2014, pp. 191-214. 


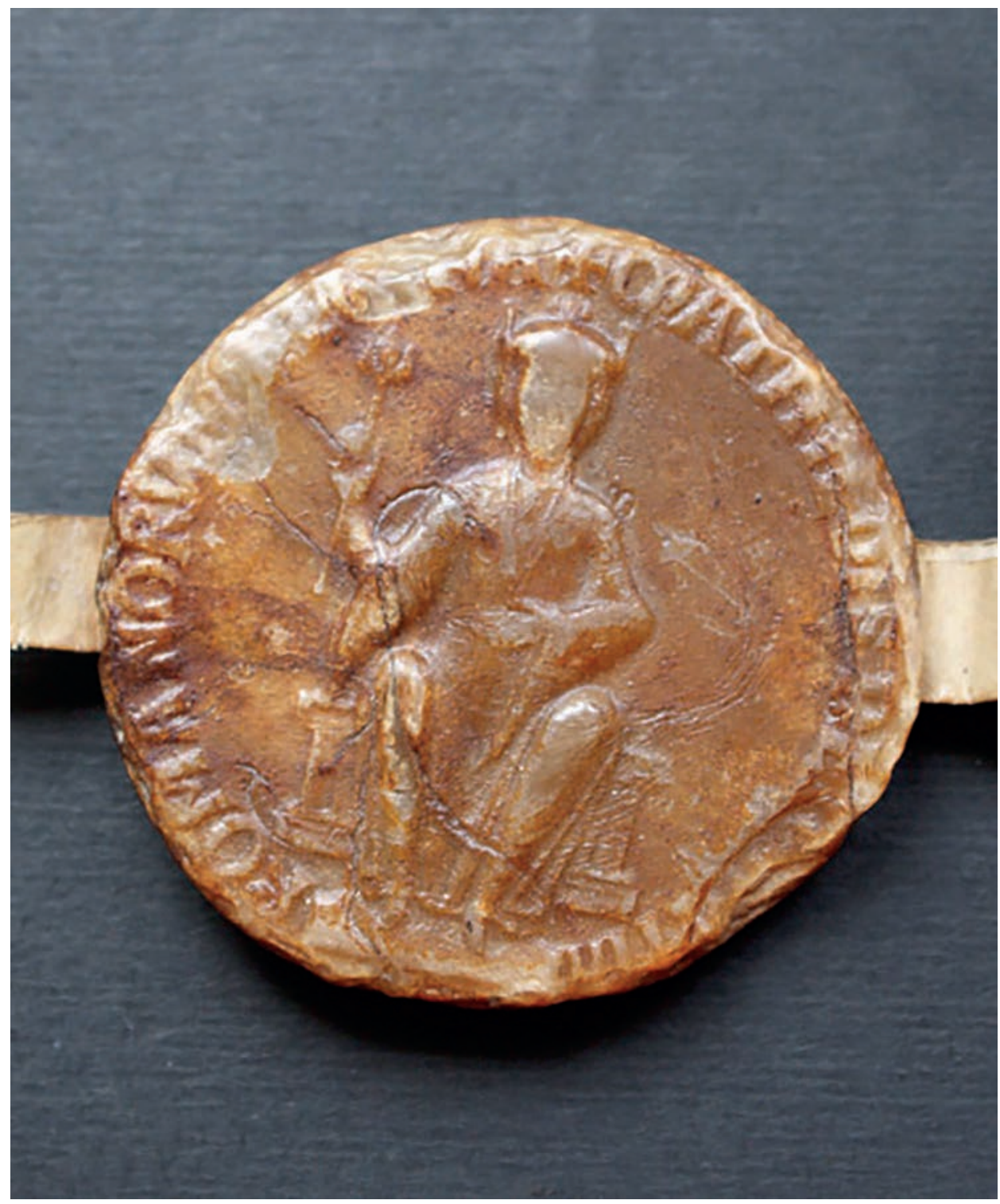

Fig. 8. Seal Empress Matilda, Ø $63 \mathrm{~mm}$. Legend: + MATHILDIS DEI GRATIA ROMANORVM REGINA. Attached to a confirmation by the Empress Matilda of a grant, 1141-1143 (SJP/19). Archive Centre, King's College Cambridge.

http://www.kings.cam.ac.uk/archive-centre/archive-month/january-2010.html 
seal $)^{30}$. This personal character distinguishes seals from coins, which were usually issued in great quantities, and whose production was overseen by the moneyer as well as by the issuing authority.

Like her contemporaries, Matilda was aware that the seal was a powerful tool in the creation of her identity and that imprinting it on parchment reinforced its power even further. On Matilda's seal, the inscription reads + MATHILDIS DEI GRATIA ROMANORVM REGINA ("Matilda by the Grace of God Queen of the Romans"), a clear reference to her status as queen of the Holy Roman Empire - she was crowned 25 July 1110 in Mainz - which she held due to her marriage to the German Roman Emperor Henry V. Seated on a throne, crowned, and holding a scepter in her right hand, Matilda is unmistakably portrayed as a ruler. The majestic iconography, as well as its single-sided design, was modeled after that of her husband Henry V. The masculine character of Matilda's seal is further corroborated by its round shape, a typical shape for German empresses but an unusual choice for Anglo-Norman women because their seals usually were pointed oval ${ }^{31}$.

Matilda's mother, Matilda of Scotland, who was crowned the day she married, owned a pointed oval seal [fig. 9]. On it, she is depicted standing, wearing a crown and a long embroidered robe that falls in lavish folds over her feet, as well as a mantle that is fastened with a round brooch. In her right hand the queen holds a scepter surmounted by a dove, and in her left an orb topped by a cross. Her royal status is further underscored by the seal's legend saying SIGILLUM. MATHILDIS. SECUNDAE. DEI. GRACIA. REGINAE. ANGLIE ("Seal of Matilda the Second, by the Grace of God Queen of the English"). At first sight, Matilda of Scotland's seal design may be traditional when compared with that of her daughter, but the presence of the orb as well as the scepter turns this seal into a strong statement of regal status. Her daughter Matilda carries neither orb nor sword and, in addition, the size of her seal is smaller compared to that of her first husband, father, and even her mother. While it could be argued that this makes an interpretation of Matilda's seal as a clear expression of kingship less convincing, in my opinion, too much has been made of the absence of the orb on Empress Matilda's seal and the smaller dimension as signs of her limited power ${ }^{32}$. It is true that regalia and size mattered, but the seal's imperial design in combination with the act of imprinting

30. BEDOS-REZAK, Brigitte Miriam: "In Search of a Semiotic Paradigm: The Matter of Sealing in Medieval Thought and Praxis (1050-1400)". In ADAMS, Noël, CHERRY, John, and ROBINSON, James (eds.): Good Impressions: Image and Authority in Medieval Seals. London, The British Museum, 2008, pp. 1-7.

31. STIELDORF, 2000, op . cit; ; and KLÖSSEL-LUCKHARDT, 2017, op. cit.

32. According to Kathleen Nolan Matilda bears an orb. See: NOLAN, 2009, op. cit., 70. 


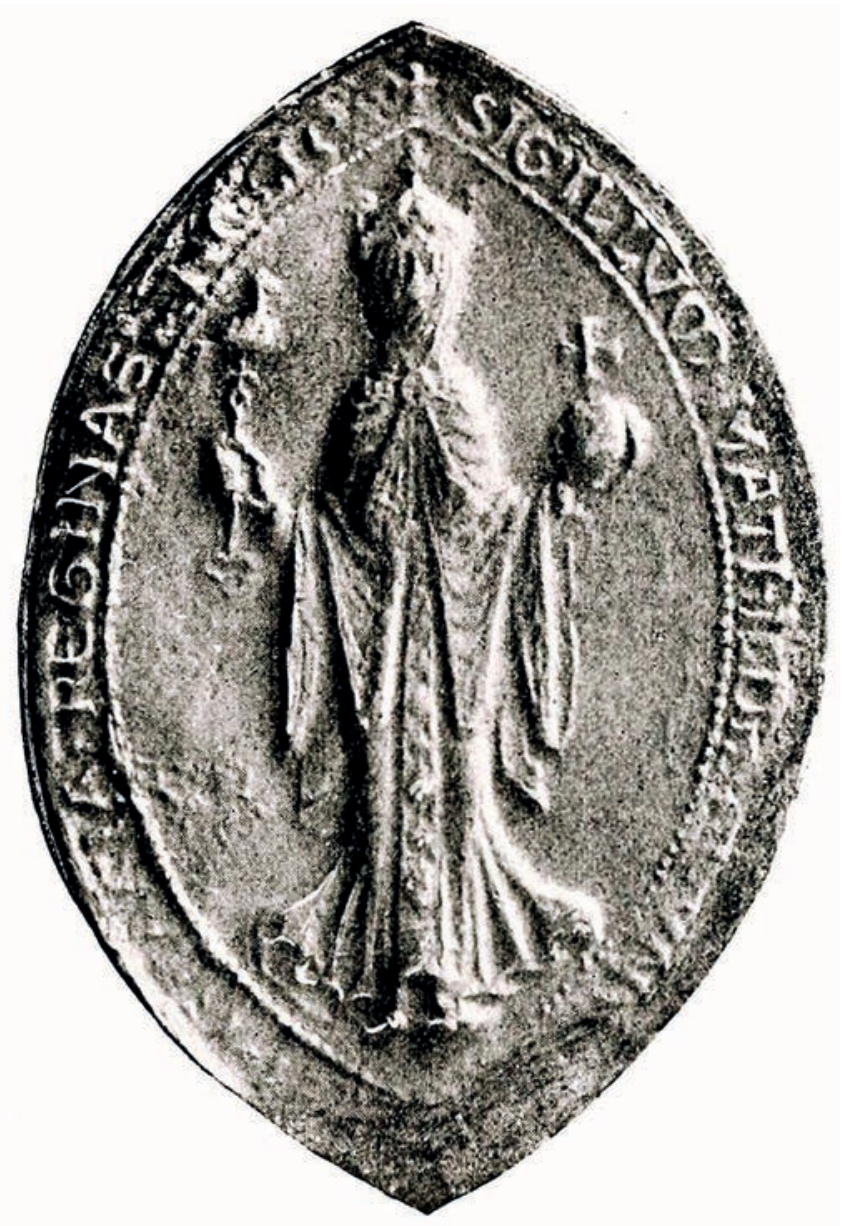

Fig. 9.- Seal Queen Matilda, first wife of Henry I, 80 x 56 mm. SIGILLUM. MATHILDIS. SECUNDAE. DEI. GRACIA. REGINAE. ANGLIE. (C) Public Domain. https://en.wikipedia.org/wiki/Matilda_of_Scotland\#/media/File:Maud_of_Scotland.jpg

the queen's image in wax made it an equally powerful instrument in the creation and preservation of a royal image ${ }^{33}$.

Matilda's royal image was treasured in the abbey of Bec-Hellouin, which she patronized extensively and chose as her burial place. In the abbey, she was

33. I do not agree with Nolan's statement "What makes Matilda's seal remarkable, even shocking, was that she continued to use its imperial imagery once she returned to France as an Angevin countess and would-be queen of England.” See: NOLAN, 2009, op. cit., 71. It was Matilda's prerogative to maintain this image of German queenship. Also, given that Matilda did not officially carry the title of queen of the English, the German iconography and title solved this problem. 
remembered for her (biological) qualities as royal daughter, imperial spouse, and royal mother ${ }^{34}$. Some medieval writers, however, underline Matilda's other characteristics. Matilda's epitaph written by Bishop Arnulf of Lisieux (d. 1184), a supporter of King Stephen, states that, despite being a woman, Matilda was without feminine weakness, as such indicating that she possessed the male quality of strength ${ }^{35}$. In addition, Ralph of Diceto (d. c. 1202), dean of St Paul's Cathedral in London, attributed "a manly mind in a female body" to the empress, which made this virtuous woman an excellent example for her granddaughter ${ }^{36}$. The most vivid illustration of Matilda's manlike behavior is found in the first continuation of the Chronicon ex chronicis, which ends in 1141, where she "once more mounted her horse, male fashion," after having fled King Stephen's attacks on Winchester ${ }^{37}$. By following the iconography of male predecessors, it is precisely this more masculine image that Matilda communicated through her coins and seal. As will become clear in the next section, Duchess Bertha employed a similar strategy with her seals, using them as powerful symbols of status and lordship.

\section{4.-Duchess Bertha of Lorraine: Riding Astride Like a Man}

34. The epitaph on her now lost tomb read: Ortu magna, viro major, sed maxima partu / Hic jacet Henrici filia, sponsa, parens ("Great by birth, greater by marriage, greatest in her offspring: here lies the daughter, wife, and mother of Henry"). Cited from: CHIBNALL, 1999, op. cit., 191. Although the emphasis on motherhood could have been Matilda's choice —in cooperation with the monks of Bec who in their Chronicle also refer to her as mother - it also raises the question whether her son Henry II could have been involved in the construction of her grave monument. In the inventory of Bec-Hellouin Matilda is styled as imperatrix, see Histoire de l'Abbey du Bec. In the thirteenthcentury Chronique du Bec her second marriage to Geoffrey count of Anjou is mentioned as well as being queen of England, see CHIBNALL, Marjorie: "The Empress Matilda and Bec-Hellouin". In BROWN, Reginald Allan (ed.): Proceedings of the Battle Conference 1987. Woodbridge, Boydell \& Brewer, 1988, p. 48.

35. Virtutum titulis humani culmen honoris / Excessit mulier, nil mulieris habens. Cited from: CHIBNALL, 1999, op. cit., 191 n. 58.

36. [...] Matildis emperatrices, et in ejus femineo corpore virile pectus, STUBBS, W. (ed.): Radulfi de Diceto Decani Lundoniensis Opera Historica (Rolls, Rerum Britannicarum Medii Aevi Scriptores 68), 2 vols. London, Longman, 1876, vol. 2, p. 17.

37. Unde hortantibus suis, equo iterum usu masculino supposita, Florentii Wigorniensis monachi Chronicon ex chronicis: ab adventu Hengesti et Horsi in Britanniam usque ad annum M.C.XVII., 2 vols. London, Sumptibus Societatis, 1848-1849, vol. 2, p. 134. Chibnall mentions this episode in connection to the flight narrated in the Gesta Stephani which portrays Matilda as having "a mind steeled and unbroken in adversity," and interprets this image positively. See: CHIBNALL, 1999, op. cit., 114. For a misogynist interpretation, see ANDERSON, Carolyn: "Narrating Matilda, "Lady of the English," in the "Historia Novella", the "Gesta Stephani", and Wace's "Roman de Rou": The Desire for Land and Order". Clio. A journal of literature, history and the philosophy of history 29-1 (Fall 1999) 47-67. 
As the twelfth century progressed, sealing practices became more common, and the dukes of Upper Lorraine followed this trend. In 1158, Duke Matthew of Lorraine (r. 1139-1176) and his wife Bertha (b. c. 1130-d. 1194/95) authorized donations to the Order of Knights of the Hospital of Saint John of Jerusalem with the consent of their sons Simon, Frederick and Matthew. According to the closing statement in their charter, they confirmed the deed with their seals ${ }^{38}$. The three sets of slits in the surviving document indicate that at least three seals must have originally been appended. While these seals primarily served to authenticate the charter, they also demonstrate the power of the duke and duchess, and reveal the manner in which the couple sought to present themselves. The fact that multiple seals were appended to some of the ducal charters enables a study of the interplay between the seals. We will see that Bertha held two different seals, one mirroring the design of her husband Matthew and the other that of her eldest son Simon.

Bertha was the daughter of Duke Frederick of Swabia (d. 1147), who had been a supporter of Emperor Henry V and Queen-Empress Matilda. Her brother, Frederick Barbarossa (d. 1190), would become King of the Romans in 1152 and subsequently Holy Roman Emperor in 1155, thereby further boosting Bertha's status. Long before her brother became king, Bertha had married Duke Matthew of Lorraine (c. 1138), a marriage that bestowed upon her the title of duchess. The couple had a fertile marriage that produced five sons and two daughters ${ }^{39}$. In this environment, Bertha managed to visually present herself as an active ruler, testifying to and affirming the power she held. Perhaps because Bertha of Lorraine was a duchess, rather than a queen, her rule was not contested as much as that of Urraca and Matilda. However, it seems that her dynastic background and the close cooperation, initially with her husband and later with her sons, also contributed to the successful exercise of her power.

The charter evidence indicates that the duchess was frequently involved in her husband's territorial affairs ${ }^{40}$. Bertha acted together with her husband when the granting of privileges or the donation of lands was concerned. She also consented to her husband's decisions, witnessed the agreements that had been put

38. hanc cartulam sigillorum nostrorum et filiorum nostrorum confirmamus, see DUVERNOY, Émile: Le duc de Lorraine Mathieu Ier (1139-1176). Paris, Picard, 1904, no. 49. This charter is in Archives Départementales de Meurthe-et-Moselle, H 3049. A transcription is available in the database Chartes originales conservées en France (1121-1220), http://www.cn-telma.fr/originaux2/ charte268231/. Accessed 27 December 2017.

39. For their offspring, see POULL, Georges: La maison ducale de Lorraine devenue la maison impériale et royale d'Autriche, de Hongrie et de Bohême. Nancy, Presses universitaires de Nancy, 1991, pp. 37-39.

40. JASPERSE, Jitske: "To Have and to Hold: Coins and Seals as Evidence for Motherly Authority". In FLEINER, Carey, and WOODACRE, Elena (eds): Royal Mothers and Their Ruling Children. Wielding Political Authority from Antiquity to the Early Modern Era. Basingstoke, Palgrave Macmillan, 2015, pp. 83-104. 
on parchment, and on other occasions acted alone. A charter issued by Matthew and Bertha between 25 March and 13 May 1176, the year the duke died, is of particular interest. The charter, to which both their seals were attached, describes how the ducal couple donated their allods of Saint-Hilaire located in the town of Port to the church of Saint-Nicolas-de-Port. In return for this donation, the anniversary of the duke was to be celebrated each year in the abbey of Gorze after his death, and during his lifetime the monks at this abbey were to pray regularly for the couple and their children. According to the document, all the stipulations were confirmed with their seals ${ }^{41}$.

Indeed, the remains of seals can be detected. The plica, or fold that reinforced the lower edge of the charter, reveals two sets of slits through which the cords of the seals were passed. The seal at the central green-brownish cord is missing, but that on the left green cord is still there, even though rather damaged [fig. 10a-b]. On this red wax seal a woman riding a horse side-saddle to the left is portrayed and part of the legend reads INGORUM DUCISS, referring to Bertha as duchess of Lorraine ${ }^{42}$. The other seal was doubtlessly that of her husband Matthew, of whom a brown-reddish seal survives that depicts him as a knight on horseback, galloping to the left while holding a shield and sword and wearing a helmet [fig. 11] ${ }^{43}$. As can be inferred from the phrasing in the charter and the two seals that were appended originally, Matthew and Bertha operated together. When reading the seals from left to right, the direction in which the charter would be read, Bertha rides side-saddle, following her husband. However, since both spouses are depicted riding towards the left, it is in fact Matthew who follows his wife. It is impossible to say whether this 'double' reading was deliberate, but it does emphasize their co-rule visually.

41. IN NOMINE PATRIS ET FILII ET SPIRITUS SANCTI. Matheus Dei gratia Lotharingie dux et marchio, et Bertha ducissa omnibus fidelibus IN PERPETUUM [...] Quod factum ne qua posterorum possit oblivione deleri, presens privilegium sigillis nostris confirmamus, quodque filii nostri non solum laudaverunt, sed et sigillis suis similiter confirmaverunt in testimonium illis. For the transcription, see Chartes originales conservées en France (1121-1220), http://www.cn-telma. fr/originaux2/charte268037/. Accessed 27 December 2017. Also DUVERNOY, 1904, op. cit., no. 86. The charter is kept in Archives Départementales de Meurthe-et-Moselle, G 449. Bertha was the main issuer of a charter dated around 1168 saying: Berta Ducissa notum facio tam praesentibus quam posteris quod maritus \& dominus meus Mathaeus Lotharingiae Dux \& Marchio ... sigille mei impressione signavi [...]. See Duvernoy, 1904: no. 69 and p. 145. The 'vidimus' of this charter is in Archives Départementales de Meurthe-et-Moselle, H 1095 and holds the remains of a green wax seal impression.

42. VAISSE, Damien: "Les sceaux lorrains du XII siècle dans le fonds de l'abbaye de Clairvaux aux Archives de l'Aube". Lotharingia 10 (2001) 179-199, at 183-184.

43. Archives Départementales de Meurthe-et-Moselle, B 476. See Duvernoy, 1904: no. 76. A similar seal is appended to a charter dated 1140 in Archives Départementales de Meurthe-et-Moselle H 1177. See: DUVERNOY 1904, op. cit., no. 5; and Chartes originales conservées en France (11211220), http://www.cn-telma.fr/originaux2/charte268212/. Accessed 27 December 2017. 


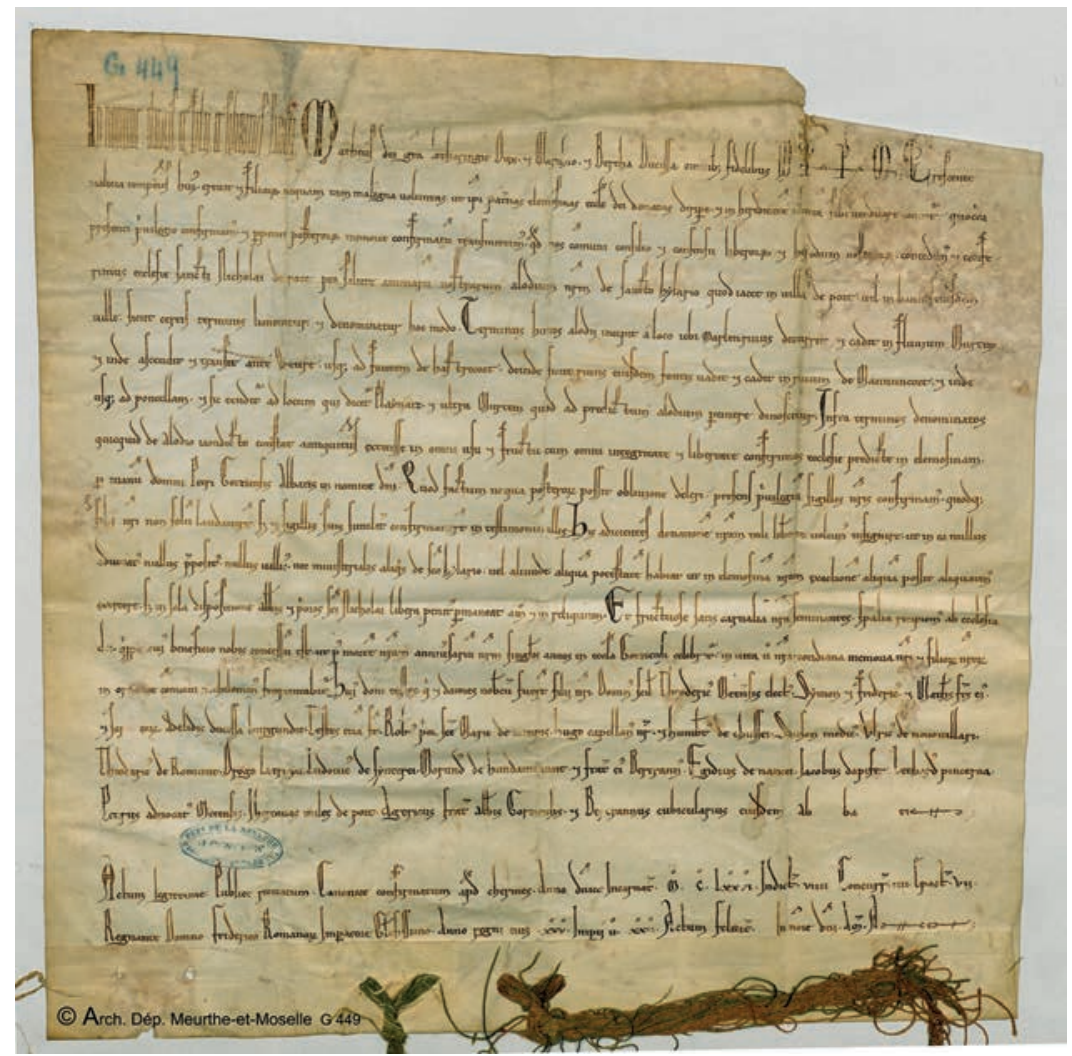

Fig. 10a.-Charter issued by Duke Matthew of Lorraine and Duchess Bertha, 25 March-13 May 1176.

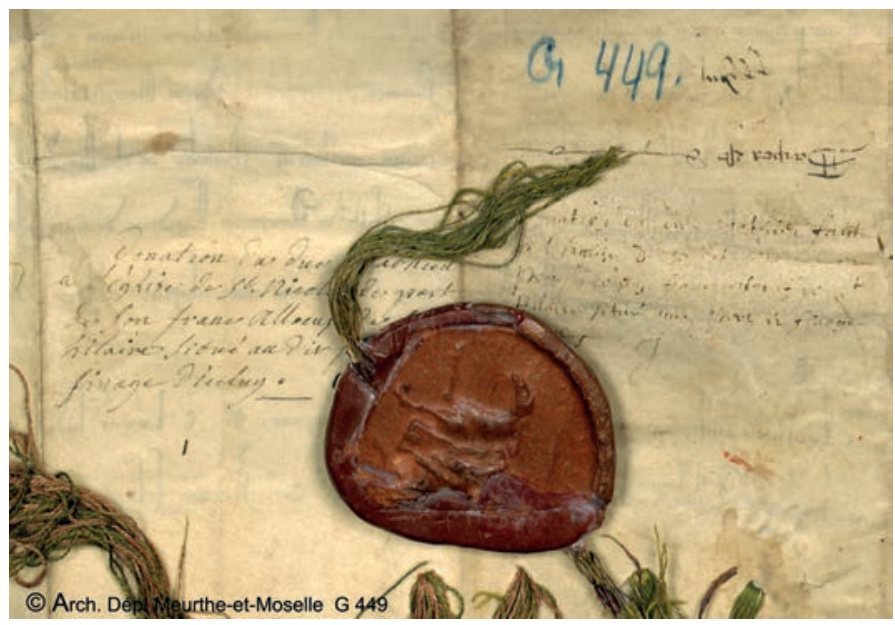

Fig. 10b. - Seal of Bertha on horseback. Archives Départementales de Meurthe-et-Moselle, G 449. 


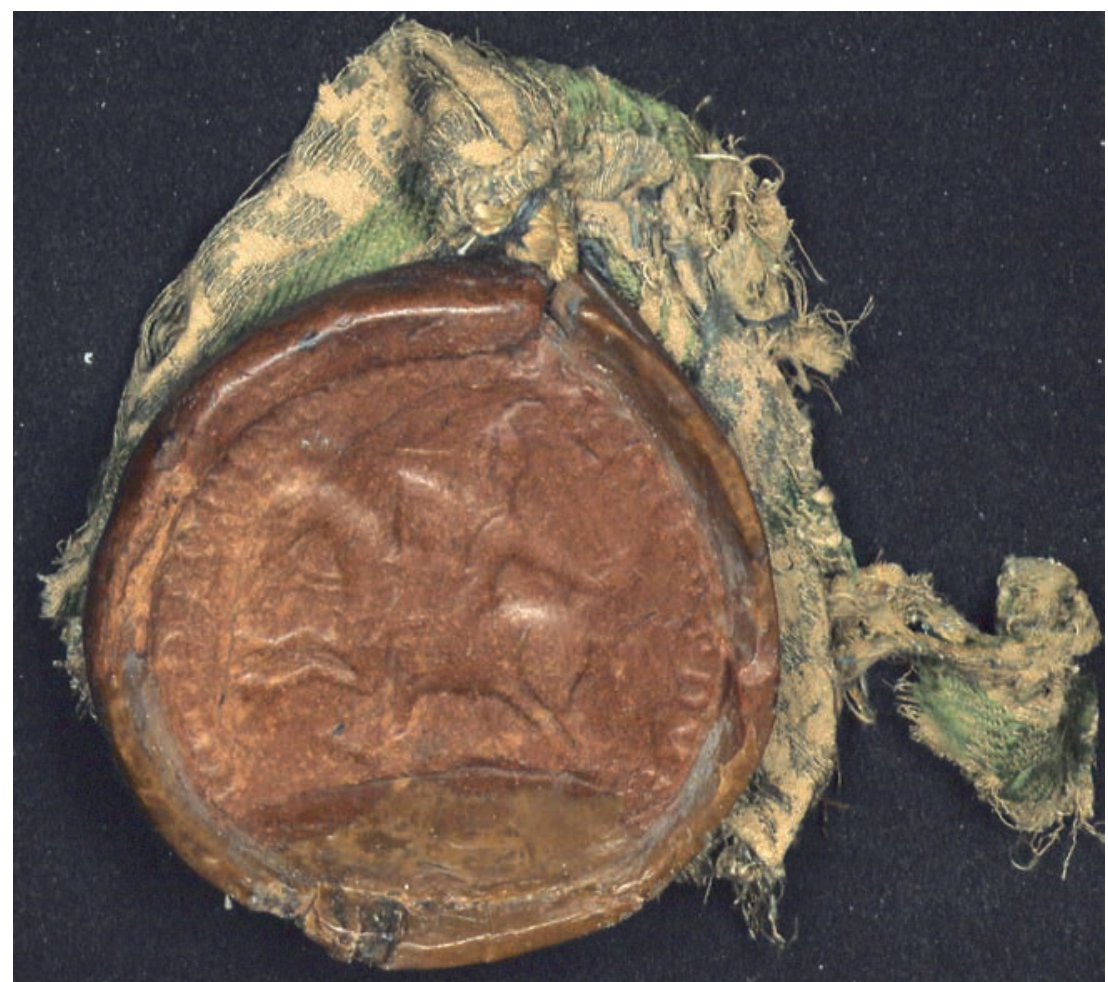

\section{(C) Arch. Dép. Meurthe-et-Moselle B 476}

Fig. 11.-Seal of Duke Matthew on horseback, 1172. Archives Départementales de Meurthe-et-Moselle, B 476.

The iconography of the equestrian holding a sword was introduced around 1100 and although a male prerogative ${ }^{44}$, it seems that Bertha's seal was a feminized version based on this male model. With Bertha's seal we have an early example of an equestrian seal for women, a design that would be used by other women as well but that would never become common ${ }^{45}$. Another surviving seal belonging to Bertha evidences that she modified her first seal design after her husband had died in May 1176. It was certainly not uncommon that changes in personal and

44. NIEUS, Jean-François: "Early Aristocratic Seals: An Anglo-Norman Success Story". Anglo-Norman Studies 28 (2016) 97-123.

45. Other examples of this equestrian iconography on seals are: Countess Constance of Toulouse (d. 1176), Queen Sancha of Aragon (d. 1208), Countess Aleydis of Holland (d. after 1238), Countess Joana of Flanders (d. 1244), and her sister Countess Margaret of Flanders (d. 1280). Yet none of them are depicted in male fashion. 
political circumstances, such as ascending to the throne or becoming a regent, led to new or altered seals ${ }^{46}$. Upon her husband's death, Bertha gained an even more powerful position, ruling together with her son and heir Simon (b. 1145/50-d. 1207).

On the duchess's second type of coin, she is again portrayed on horseback, but this time riding astride, in other words: riding like a man. She holds a bird in her left hand while grasping the bridle with her right hand [fig. 12a-b]. This is truly a unique representation, since no other twelfth-century seal exists with a woman riding in man's fashion. Bertha would probably have overstepped her boundaries by appropriating sword and shield, but by riding astride she underscored her powerful position as widowed duchess. This seal is only known through the wax impression attached to a charter that Bertha issued together with her son Simon in $1186^{47}$. In the charter, Simon and Bertha granted a free passage through all their lands and an exemption from all taxes and tolls to the abbey of Clairvaux, which had also been advocated by Duke Matthew.

Simon's green wax seal is appended as well, and it has been identified as his third seal, used between 1182 and $1194^{48}$. Like his father before him, he is depicted on a galloping horse, wearing a helmet and holding a sword and shield. In contrast to his father's seal and the earlier seal his mother held, however, Simon is riding to the right. And so is Bertha on her second seal. In the charter Simon is mentioned first (Ego Simon dei gratia dux Lotharingie y marchonis), followed by Bertha without her ducal title (illustris mater mea Berte), indicating that Simon took the initiative to grant Clairvaux the privileges with the support of his mother. This would explain why his seal is appended at the centre of the document. The visual effect is, however, that Simon follows his mother, whose seal is attached on the right. This reading would probably not have gone unnoticed, since it is well-known that ecclesiastical receivers and issuers of charters like the abbot of Clairvaux,

46. This has been argued for the seals of Countess Jeanne of Flanders and Hainaut (r. 12061244), see JORDAN, Erin L.: "Swords, seals and coins. Rulers and the instruments of authority in thirteenth-century Flanders and Hainaut". In SOLWAY, 2015, op. cit., pp. 229-246. And we can also think of changes in design as a result of coronation to king, or the obtaining of a new princely title, which enticed William the Conqueror to come up with a completely new seal, see NIEUS, 2016, op. cit., 101.

47. VAISSE, 2001, op. cit., 183; and JASPERSE, 2015, op. cit., pp. 94-95. The same seal possibly was also attached to a charter mother and son issued together at an unknown date: Ego Symon dux Lotharingie et marchie et Berta mater mea ducissa presentibus et futuris presenti scripto notum [...] Et ut hoc factum ratum et inconvulsum processu temporum permaneat, sigillorum nostrorum auctoritate presentem paginam muniri [...]. See: PFISTER, C.: "Documents sur le prieuré Notre-Dame de Nancy". Annales de l'Est. Revue Trimestrielle 11 (1897) 88, no. 11; and DUVERNOY, Émile: "Catalogue des actes des ducs de Lorraine de 1176 à 1220". Mémoire de la Société d'archéologie Lorraine 64 (1914-1919), 137, no. 105.

48. VAISSE, 2001, op. cit., 181-183. 


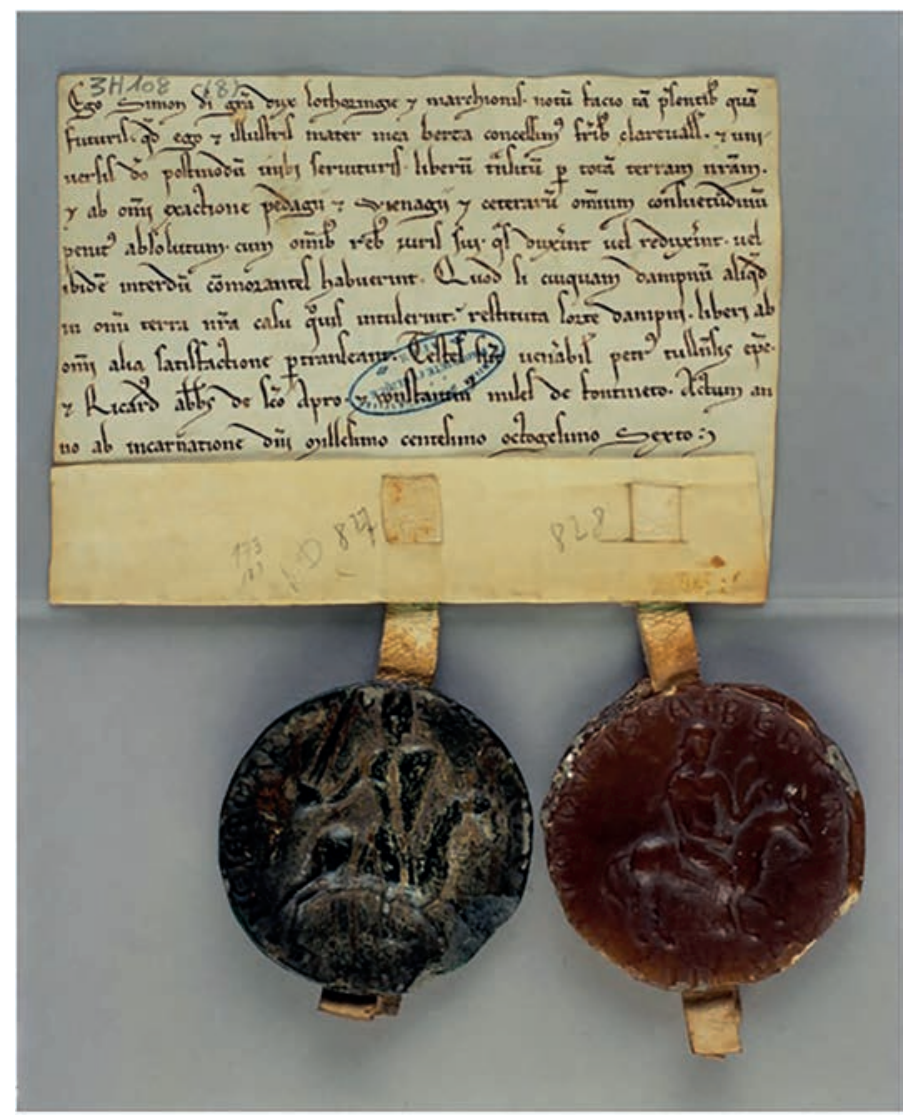

Fig. 12a.-Charter issued by Duke Simon of Lorraine and his mother Duchess Bertha, 1186. Seal Simon (left), Ø 72 $\mathrm{mm},+$ SYMON DVX [...] ORI/NGIE \& MARCHI/O (Symon dux Lothoringie et Marchio).

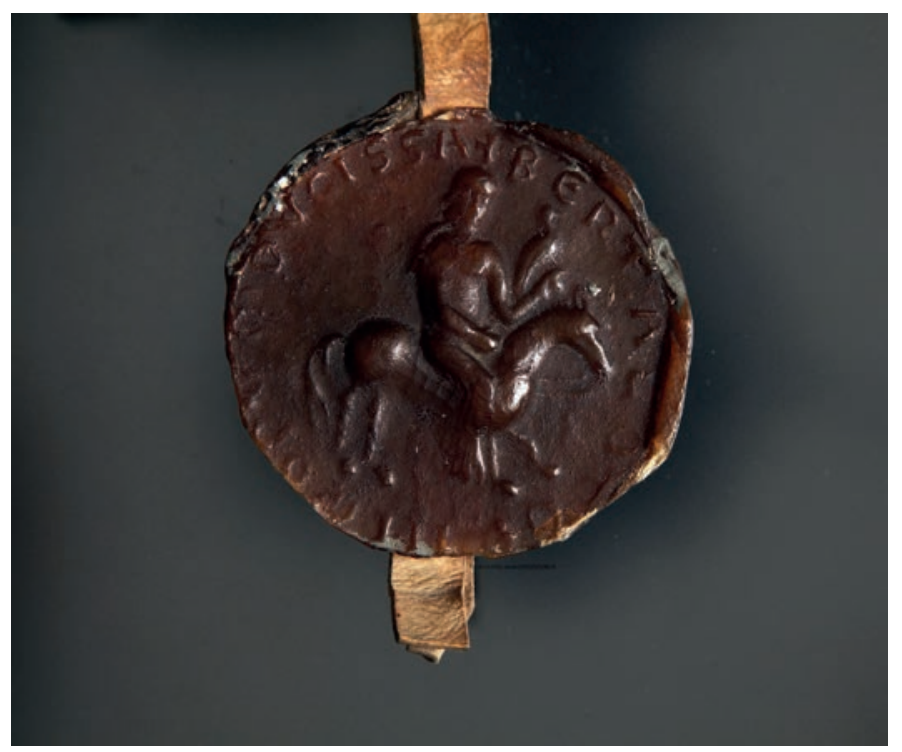

Fig. 12b.-Seal Bertha, Ø $80 \mathrm{~mm}$, + BERTA LOTORINGORVM DVCISSA (Berta Lotoringum ducissa). Archives dép. de 1'Aube PD, 3 H 108. http://www.archives-aube. $\mathrm{fr} / \mathrm{s} / 11 /$ chartes-et-sceauxde-clairvaux/3605/3-h$108 /$ ? \&debut $=0$ 
were deeply aware of the visual rhetoric of seals ${ }^{49}$. The formal composition of the wax impressions and the formal relations between several impressions affixed to the same charter were therefore likely to have made an impression.

This example of a woman riding a horse male fashion can be seen as Bertha's conscious choice to follow in the footsteps of her male relatives. By doing so she claimed a more masculine image than her contemporaries, who often held the typical female oval seals. This practice, in addition to her minting rights — which I have discussed elsewhere ${ }^{50}$ - established the duchess as a capable ruler, whose lordly powers were largely accepted. The available charter material, her seals and her coins allow us to conclude that Bertha was a shrewd politician who, with the support of family members and followers, was able to successfully bridle the duchy of Lorraine ${ }^{51}$.

\section{5.-Conclusion}

In this article, I have argued that coins and seals are valuable sources for our understanding of the way in which elite women could craft their image as rulers. For the fabrication of their ruler images, Queen Urraca, Empress Matilda, and Duchess Bertha made use of tradition as well as innovation. Through the appropriation of established designs, such as ruler portraits on coins or the round shape of seals, these women communicated that they were part of an esteemed tradition. As such, they foregrounded the origin of their claim to power with the intention of being accepted and recalled as rightful rulers. To further boost the image of the ruling authority, the three women added new elements to their coins and seals that made them stand out. Urraca described herself as king on some of her coins and was the first ruler in Iberia to be depicted seated on a throne, while in her turn Matilda was the first female ruler to be represented enthroned on seals in the Anglo-Norman realm. While it remains inconclusive whether coins' incomplete legends were purposely ambiguous, it cannot be denied that both queens made use of a masculine iconography to craft their royal identities. Although not a queen, Bertha equally secured her image of a lordly woman, this time by being represented riding astride on horseback. The secular power wielded by these women was partly coded masculine, precisely because this was the language of male aristocrats and kings who usually exercised power.

49. BEDOS-REZAK, Brigitte Miriam: When Ego Was Imago: Signs of Identity in the Middle Ages. Leiden, Brill, 2011, 109-159.

50. JASPERSE, 2015, op. cit.

51. Why Bertha's seal design remains unique in the Middle Ages as well as medieval ideas about women riding astride deserves further study. 
Coins and seals were never neutral expressions of power, but carefully carved images and inscriptions that reveal the sex, status, authority, and ambitions of their issuers. Originating directly from the power of a lordly woman or man, they convey how rulers represented themselves and consequently how they wished to be recognized and recollected. As such, they were part of a wider medieval culture of remembrance to which the creation of artefacts and architecture was crucial. Many medieval artworks, such as tombs, manuscripts, and textiles, were made to function within the context of liturgical commemoration ${ }^{52}$. In addition, medieval people created commemorative objects to be used in profane settings, such as histories about contemporary rulers and their ancestors, or rings given to loved ones as tokens of affection, safety, or death ${ }^{53}$. Falling within these two realms, the coins and seals discussed here functioned as commemorative objects to their medieval users. To modern medievalists, these small but important items serve as reminders that thinking in binary oppositions about medieval men and women does not necessarily do justice to the realities they dealt with, whether this was issuing coinage or mounting a horse, male fashion.

\section{6.-Bibliography}

ANDERSON, Carolyn: "Narrating Matilda, "Lady of the English," in the "Historia Novella", the "Gesta Stephani", and Wace's "Roman de Rou": The Desire for Land and Order". Clio. A journal of literature, history and the philosophy of history 29-1 (1999), 47-67.

BEDOS-REZAK, Brigitte Miriam: "Women, seals and power in medieval France, 1150-1350". In ERLER, M. and KOWALESKI, M. (eds.): Women and power in the Middle Ages. Athens, Ga., and London, The University of Georgia Press, 1988, pp. 61-82.

— "In Search of a Semiotic Paradigm: The Matter of Sealing in Medieval Thought and Praxis (10501400)". In ADAMS, Noël, CHERRY, John and ROBINSON, James (eds.): Good Impressions: Image and Authority in Medieval Seals. London: The British Museum, 2008, pp. 1-7.

- When Ego Was Imago: Signs of Identity in the Middle Ages. Leiden, Brill, 2011.

BIJSTERVELD, Arnoud-Jan A.: "The medieval gift as agent of social bonding and political power:

52. BIJSTERVELD, Arnoud-Jan A.: "The medieval gift as agent of social bonding and political power: A comparative approach". In COHEN, Esther and JONG, DE Mayke B. (eds.): Medieval transformations: Texts, power and gifts in context. Leiden, Brill, 2001, pp. 133-134; OEXLE, Otto Gerhard: "Memoria und Memorialbild". In SCHMID, Karl and WOLLASCH, Joachim (eds.): $M e-$ moria. Der geschichtliche Zeugniswert des liturgischen Gedenkens. München, Fink, 1984, p. 394. For a short overview of different interpretations of memoria and Spanish studies, see MARTÍNEZ SOPENA, Pascual and RODRÍGUEZ, Ana: "Introducción". In MARTÍNEZ SOPENA, Pascual and RODRÍGUEZ, Ana (eds.): La construcción medieval de la memoria regia. Valencia, Publicacions Universitat de València, 2011, pp. 11-20. The Dutch project Medieval Memoria Online (MeMO) highlights the importance of material culture in liturgical commemoration, see http://memo.hum.uu.nl/.

53. VAN HOUTS, Elisabeth: Memory and gender in medieval Europe 900-1200. Houndsmills, MacMillan Press LTD, 1999. On rings, see PAUL, Nicolas L.: To follow in their footsteps: The crusades and family memory in the high Middle Ages. Ithaca, Cornell University Press, 2012, pp. 106-110. 
A comparative approach". In COHEN, Esther and JONG, DE Mayke B. (eds.): Medieval transformations: Texts, power and gifts in context. Leiden, Brill, 2001, pp. 123-156.

BROOKE, George Cyril: A catalogue of English coins in the British Museum: The Norman Kings. London, British Museum, 1916.

CARLESS DAVID, Henry William, WHITWELL, Robert Jowitt, and JOHNSON, Charles (eds.): Regesta regum anglo-normannorum, 1066-1154, 3 vols. Oxford, Clarendon Press, 1913.

CAVERO, Gregoria: "Sancha Raimúndez: An infanta in the exercise of her power". Imago Temporis. Medium Aevum 7 (2013) 271-297.

CAYROL BERNARDO, Laura: "De infantas, domnae y Deo votae. Algunas reflexiones en torno al infantado y sus senoras". SVMMA 3 (2014) 5-23.

CHIBNALL, Marjorie: "The Empress Matilda and Bec-Hellouin". In BROWN, Reginald Allan (ed.): Proceedings of the Battle Conference 1987. Woodbridge, Boydell \& Brewer, 1988, pp. 35-48.

CHIBNALL, Marjorie: The Empress Matilda: Queen Consort, Queen Mother and Lady of the English. Oxford, Blackwell Publishers, 1999 [1991].

— "The Charters of the Empress Matilda". In GARNET, George and HUDSON, John (eds.): Law and government in medieval England and Normandy: Essays in honor of Sir James Holt. Cambridge, Cambridge University Press, 1994, pp. 276-298.

CRUSAFONT, Miguel, BALAGUER, Anna M. and GRIERSON, Philip (eds.): Medieval European coinage: With a catalogue of the coins in the Fitzwilliam Museum, Cambridge. 6: The Iberian Peninsula. Cambridge, Cambridge University Press, 2013.

DUVERNOY, Émile (1904): Le duc de Lorraine Mathieu Ier (1139-1176). Paris, Picard.

— "Catalogue des actes des ducs de Lorraine de 1176 à 1220." Mémoire de la Société d'archéologie Lorraine 64 (1914), 121-306.

Florentii Wigorniensis monachi Chronicon ex chronicis: ab adventu Hengesti et Horsi in Britanniam usque ad annum M.C.XVII., 2 vols. London, Sumptibus Societatis, 1848-1849.

HENRIET, Patrick: "Infantes, Infantaticum. Remarques introductives". e-Spania[En ligne], 5 | juin 2008, mis en ligne le 29 janvier 2014. URL: http://e-spania.revues.org/12593.

JASPERSE, Jitske: "A coin bearing testimony to Duchess Matilda as consors regni". Haskins Society Journal 26 (2014), pp. 169-190.

— "To Have and to Hold: Coins and Seals as Evidence for Motherly Authority". In FLEINER, Carey, and WOODACRE, Elena (eds.): Royal Mothers and Their Ruling Children: Wielding Political Authority from Antiquity to the Early Modern Era. Basingstoke, Palgrave Macmillan, 2015, pp. 83-104.

JOHNS, Susan M.: Noblewomen, aristocracy and power in the twelfth-century Anglo-Norman Realm. Manchester: Manchester University Press, 2003.

JORDAN, Erin L.: "Swords, seals and coins. Rulers and the instruments of authority in thirteenthcentury Flanders and Hainaut". In SOLWAY, Susan (ed.): Medieval coins and seals: Constructing identity, signifying power. Turnhout, Brepols, 2015, pp. 229-246.

KLÖSSEL-LUCKHARDT, Barbara: "Et sigillo illustris uxoris nostre - Weibliche Repräsentation in frühen Frauensiegeln des Welfenhauses". In LEMBKE, Katja, LUCKHARDT, Jochen and STAMM, Rainer (eds.): Niederdeutsche Beiträge zur Kunstgeschichte, Neue Folge, Band 2, Petersberg, Michael Imhof Verlag, 2017, pp. 27-52.

LOPRETE, Kimberly A.: "Gendering viragos. Medieval perceptions of powerful women". In MEEK, Catherine and LAWLESS, Catherine (eds.): Studies on medieval and early modern women 4: Victims or viragos? Dublin, Four Courts Press, 2005, pp. 17-38.

— "The gender of lordly women. The case of Adela of Blois". In MEEK, Christine and LAWLESS, Catherine (eds.): Pawns or players? Studies on medieval and early modern women. Dublin, Four Courts Press, 2013, pp. 90-110.

MACK, R.P.: "Stephen and the Anarchy 1135-1154”. British Numismatic Journal 35 (1966), 38-112. 
MARTIN, Therese: "The art of a reigning queen as dynastic propaganda in twelfth-century Spain". Speculum 80-4 (2005), 1134-1171.

- Queen as king: Politics and architectural propaganda in twelfth-century Spain. Leiden, Brill, 2006.

MARTÍNEZ SOPENA, Pascual and RODRÍGUEZ, Ana: "Introducción”. In MARTÍNEZ SOPENA, Pascual and RODRÍGUEZ, Ana (eds.): La construcción medieval de la memoria regia. Valencia, Publicacions Universitat de València, 2011, pp. 11-20.

MONTER, William: "Gendered sovereignty: Numismatics and female monarchs in Europe, 13001800". Journal of Interdisciplinary History 41-4 (2011), 533-564.

NIELEN, Marie-Adélaïde: Corpus des sceaux français du Moyen âge 3. Tome III, Les sceaux des reines et des enfants de France. Paris, Service interministériel des Archives de France, 2011.

NIEUS, Jean-François: "Early Aristocratic Seals: An Anglo-Norman Success Story". Anglo-Norman Studies 28 (2016), 97-123.

NOLAN, Kathleen: Queens in stone and silver: The creation of a visual imagery of queenship in Capetian France. New York, Palgrave Macmillan, 2009.

OEXLE, Otto Gerhard: "Memoria und Memorialbild". In SCHMID, Karl and WOLLASCH, Joachim (eds.): Memoria. Der geschichtliche Zeugniswert des liturgischen Gedenkens. München, Fink, 1984, pp. 384-440.

PALLARÉS MÉNDEZ, María del Carmen and PORTELA SILVA, Ermelindo: La reina Urraca. Donostia, Nerea, 2006.

PAUL, Nicolas L.: To follow in their footsteps: The crusades and family memory in the high Middle Ages. Ithaca, Cornell University Press, 2012.

PFISTER, C.: "Documents sur le prieuré Notre-Dame de Nancy". Annales de l'Est. Revue Trimestrielle 11 (1897), 77-176.

POULL, Georges: La maison ducale de Lorraine devenue la maison impériale et royale d'Autriche, de Hongrie et de Bohême. Nancy, Presses universitaires de Nancy, 1991.

ROMA VALDÉS, Antonio: "Notas sobre las acuñaciones medievales leonesas: primeros escritos conocidos y las emisiones de Doña Urraca". OMNI 10-7 (2016), 56-73.

RUIZ ALBI, Irene: La Reina doña Urraca (1109-1126): Cancillería y colección diplomática. León, Centro de Estudios e investigación "San Isidoro". Caja España de Inversiones y Archivo Histórico Diocesano, 2003.

SERRANO COLL, Marta: "Iconografía de género. Los sellos de las reinas de Aragón en la Edad Media (siglos XII-XVI)". Emblemata 12 (2006), 15-52.

SOLWAY, Susan: "Introduction". In SOLWAY, Susan (ed.): Medieval coins and seals: constructing identity, signifying power. Turnhout, Brepols, 2015, pp. 9-20.

STAHL, Alan M.: "Coinage in the name of medieval women". In ROSENTHAL, Joel T. (ed.): Medieval women and the sources of medieval history. Athens, Ga., The University of Georgia Press, 1990, pp. 321-341.

STIELDORF, Andrea: "Die Siegel der Herrscherinnen. Siegelführung und Siegelbilder der deutschen Kaiserinnen und Königinnen”. Rheinische Vierteljahrsblätter 64 (2000), 1-44.

STUBBS, W. (ed.): Radulfi de Diceto Decani Lundoniensis Opera Historica (Rolls, Rerum Britannicarum Medii Aevi Scriptores 68), 2 vols. London, Longman, 1876.

TODESCA, James J.: What touches all: Coinage and monetary policy in Leon-Castile to $1230(\mathrm{PhD}$ diss.). Fordham University, New York, 1996.

VAISSE, Damien: "Les sceaux lorrains du XII siècle dans le fonds de l'abbaye de Clairvaux aux Archives de l'Aube". Lotharingia 10 (2011), 179-199.

VAN HOUTS, Elisabeth: Memory and gender in medieval Europe 900-1200. Houndsmills, MacMillan Press LTD, 1999. 


\section{Websites}

Chartes originales conservées en France (1121-1220), Traitement électronique des manuscrits et des archives, http://www.cn-telma.fr.

Medieval Memoria Online (MeMO), http://memo.hum.uu.nl/.

Numismatico digital, http://www.numismaticodigital.com/noticia/9243/subastas-nacionales/piezasmuy-interesantes-en-la-subasta-144-de-jesus-vico.html.

The British Museum Collection Online, http://www.britishmuseum.org/research/collection_online/ search.aspx. 